\title{
Arabic Lexicology: Systematics of Compiling an Arabic Dictionary and Its Lexicologists
}

\begin{abstract}
Iis Susiawati ${ }^{1}$,Email: iis.susiawati20@mhs.uinjkt.ac.id, Universitas Islam Negeri Syarif Hidayatullah Jakarta, Indonesia Ahmad Royani², Email: ahmadroyani@uinjkt.ac.id, Universitas Islam Negeri Syarif Hidayatullah Jakarta, Indonesia Ahmad Dardiri ${ }^{3}$, Email: ahmaddardiri@gmail.com, Universitas Islam Negeri Syarif Hidayatullah Jakarta, Indonesia
\end{abstract}

\section{(c) (1) ()}

This is an open access article under the CC-BY-SA license

(C)2021 by the authors. Submitted for possible open access publication under the terms and conditions of the Creative Commons Attribution-ShareAlike 4.0 International License-(CC-BY-SA) (https://creativecommons.org/licenses/by-sa/4.0/)

doi) DOI: http://dx.doi.org/10.30983/ huruf.v1i1.4923

\begin{abstract}
This article discusses the Arabic codification process, the systematic compilation of Arabic dictionaries, and the stories of Arabic lexicologists and their works from time to time. This study uses a library approach, with data collection techniques through reviewing and searching for library materials from books, journals, and other relevant sources. The data collected were analyzed by the text study method to describe the content in detail and aim to find out the contribution of dictionaries to the development of lexicology, how the process of compiling dictionaries was carried out by lexicologists, and the characteristics of dictionaries from time to time with their advantages and disadvantages. The results are: 1) The dictionary as a reference book in finding the meaning of words is certainly very helpful in the development of lexicology. 2) Lexicologists in producing dictionaries have struggled so hard, tirelessly, traveling from one corner of the village to another to get and understand the meaning of a word. 3) The works of lexicologists with various systematics of compiling dictionaries have characteristics with their respective advantages and disadvantages which are a major contribution to the development of lexicology as part of linguistics, especially Arabic linguistics, and literature.
\end{abstract}

Keywords: Lexicology, Systematic Compilation, Lexicologists, Arabic

\section{ملخص البحث}

يناقش هذا المقال عملية تدوين اللغة العربية والتجميع المنهجي للقواميس العربية وقصص علماء المعاجم العربية وأعمالههم من وقت لآخر. تستخدم هذه الدراسـة نهج المكتبة ، مع تقنيات جمع البيانات من خلال المراجعة والبحث عن مواد المكتبة من الكتب والمجلات والمصادر الأخرى ذات الصلة. تم تحليل البيانات التي تم جمعها باستخدام طريقة الدراسة النصية بهدف وصف المحتوى بالتفصيل بهدف معرفة مساهمة القواميس في تطوير المعجم ، وكيف تم تنفيذ عملية تجميع القواميس من قبل علماء المعاجم ، وخصائص المعجم. قواميس من وقت لآخر مع مزاياها وعيوبها. النتائج هي: 1) 


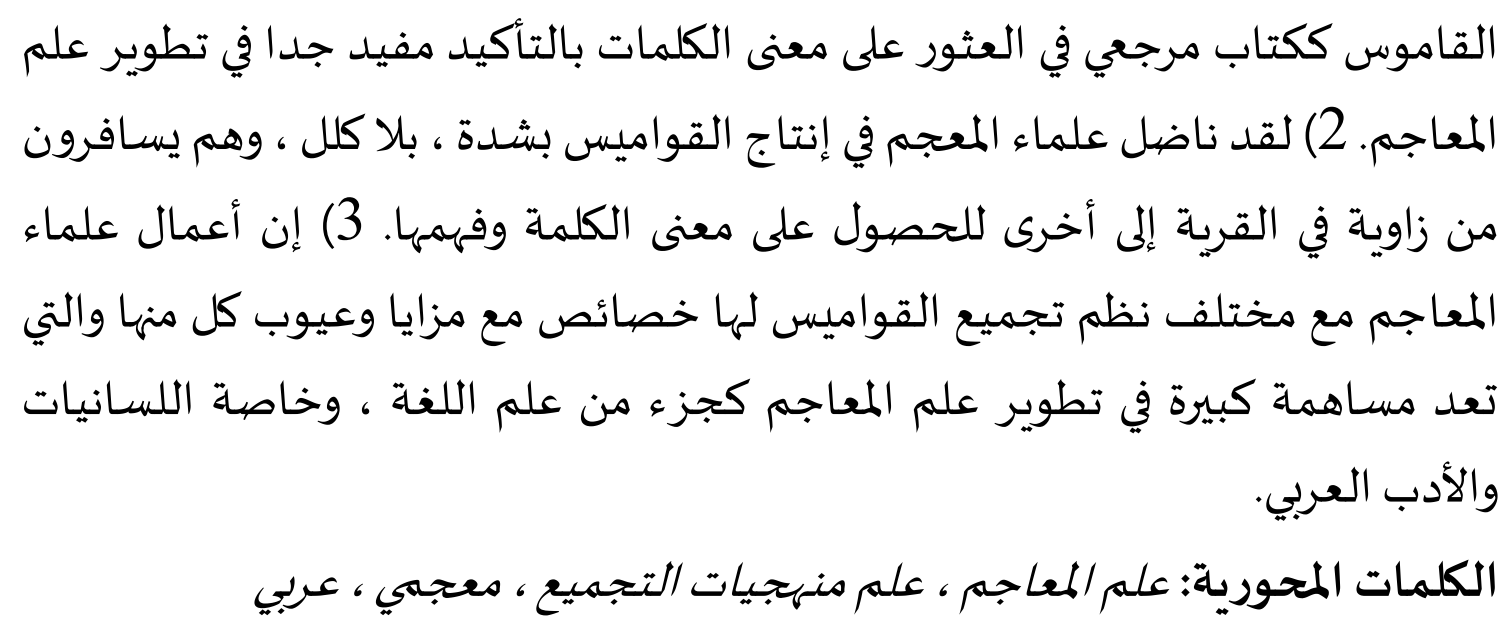

\section{A. INTRODUCTION}

A dictionary is a kind of reference book that explains the meaning of words. It serves to help someone recognize new words. In addition to explaining the meaning of words, dictionaries may also have guidelines for the designation, origin (etymology) of a word, and also examples of usage for a word. To clarify sometimes there are also illustrations in the dictionary. Dictionary is a treasure that contains the vocabulary of a language, which is ideally unlimited in number.

In addition to communication tools, language also functions as a tool for thinking or communicating media of reason for the language users themselves. The development of a language follows the development of the thoughts of language users. Meanwhile, humans will not be able to memorize and develop all the words from their language even though they have a high level of intelligence. Therefore, sometimes a person is unable to remember a word or has difficulty pronouncing the vocabulary that he wants.

So now we know the terms lexicography and lexicology. Lexicography is a branch of linguistics that studies the technique of compiling a dictionary. Activities involved in lexicography include designing, compiling, using, and evaluating a dictionary. And lexicology or dictionary science is a branch of linguistics that discusses lexical meanings contained in a dictionary, word development, changes in word meaning, and so on. With this definition, sometimes there is confusion between the definitions of the science of meaning (semantics) and lexicology. Therefore it can be said that the scope of lexicology is narrower than semantics, and lexicology is more focused on dictionaries. 
From time to time, lexicologists have played a major role in the development of Arabic linguistics and literature, including lexicology. This paper describes a little about the history of Arabic lexicology, the basics of Arabic codification, systematic compilation of Arabic dictionaries, schools of Arabic dictionaries, as well as Arab dictionary figures who are famous for their works which are still known today. and used by students and observers of the Arabic language.

\section{B. RESEARCH METHODS}

This study uses a library approach, with data collection techniques through reviewing and searching for library materials from books, journals, and other relevant sources. The data collected was analyzed by the text study method to describe the content in detail.

\section{Discussion}

\section{History of Arabic Lexicology}

A language including Arabic originally originated from spoken language (lughah manthuqah) which is used by language users to communicate with each other. Then at the next stage, the language is codified or recorded in the form of written language (lughah kitabah) which many people call a dictionary term (mu'jam). This assumption is reinforced by realistic evidence that shows how many languages have developed and then becomes extinct because they have not been codified in the record. This is because humans do not know the written culture of writing so that their spoken language disappears along with the existence of their civilization, such as Akkadian, or Babylonian, Aramaic, and so on. This phenomenon shows the importance of the dictionary as a reference language to develop meaning, collect words, preserve the language, and bequeath a civilization that can be developed. This is what underlies humans to look at the importance of written language to codify their language. ${ }^{1}$

Arabic is a language rich in vocabulary. Vocabulary in Arabic covers all areas. This can be noted based on the words codified in Arabic dictionaries. In Arabic, the formation of a single word can refer to several meanings. For example, the word which gives

\footnotetext{
${ }^{1}$ Taufiqurrochman, Leksikologi Bahasa Arab, (Yogyakarta: UIN-Malang Press, 2008), h. 183184.
} 
meaning to eyesight, springs, a country, a place, clan leader, army leader, means self, paid at once in cash, a type of currency, peeping, and the letter 'ai $>n$. There are even words that are used more than one or two words to describe one meaning or meaning that is almost the same. Terms that refer to the meaning of camel, horse, date, sword, goat, sheep, kibas, etc. are used with several words that give almost the same meaning. ${ }^{2}$

In addition to the need for language codification in written form among Arabic, Arabic characters which have a rich vocabulary and aspects of the similarity of meaning in several words, are supporting factors that make it easier for Arabs to compile a dictionary. ${ }^{3}$

Language codification activities are not just bookkeeping in the sense of recording. Codification is an unscientific transition of Arabic, in the sense that it cannot be studied scientifically, to a scientific language, a language that is subject to a system that is also followed by its scientific object. The collection of language vocabulary and the determination of methods of derivation and morphology, the determination of structural rules, and the selection of signs to eliminate ambiguity in the writing, all of which are not only called the creation of a new science, namely Arabic language, but also the creation of a new language, namely Arabic Fusha. ${ }^{4}$

At first, the process of interpreting vocabulary in Arabic began through the sima>'i method, namely taking history by linguists by listening directly to the words of the Bedouin. Then the sima>'i method shifted to the qiya>s (analogy) method, namely the meaning of words using certain theories made by linguists. One of them is the qiya $>\mathrm{s}$ method ala Khali>1 which emphasizes the derivation of words through a special technique known as taqli>b al-kalimah. ${ }^{5}$

Seeing the phenomenon of the shift from sima'i narration to qiya $>\mathrm{s}$, at least since the era of Khalil and his contemporaries who have allowed Arabic to be dynamic internally through isytiqa $>\mathrm{q}$ (derivative) to produce many invented words, then at the same time This means that the Arabic language has fortified itself from every change and development that has appeared in history. Arabic has become ahistorical, has not changed

\footnotetext{
${ }^{2}$ Azhar bin Muhammad, "Beberapa Aspek Keunikan dan Keistimewaan Bahasa Arab sebagai Bahasa Al-Qur'an”. Jurnal Teknologi, 42(E), (Juni 2005): 61-76.

${ }^{3}$ Taufiqurrochman, Leksikologi Bahasa Arab, (Yogyakarta: UIN-Malang Press, 2008), h. 186.

${ }^{4}$ Muhammad Abed Al-Jabiri, Formasi Nalar Arab, terj. Imam Khoiri, (yogyakarta: IRCiSoD), h. 131.

5 Taufiqurrochman, Leksikologi Bahasa Arab, (Yogyakarta: UIN-Malang Press, 2008), h. 188.
} 
both in terms of nahwu (grammatical), s \}araf (etymology), the meaning of words and sentences as well as their internal reproduction. The collection of language from the Bedouin people and only from them, of course has an influence, namely its characteristics that refer to their life situation. Consequently, words that cannot be referenced in the sima>'i concept adapted from nature, and within the boundaries of language formation, are seen as da>khil (uptake words) into Arabic. ${ }^{6}$

The appearance of the dictionary and the systematic arrangement of vocabulary into Arabic dictionaries also continues to change and develop innovatively from time to time. Arabic dictionaries published with different variants and characteristics have encouraged linguists to be more serious in exploring innovative and informative compilation techniques. This phenomenon gave birth to the science of lexicography or dictionary science which is not only limited to discussing the ins and outs of the lexical meaning of vocabulary but also as a science that discusses systematic selection techniques in compiling dictionaries, understanding the completeness of dictionary components, and so on. $^{7}$

\section{Fundamentals of Arabic Codification}

Before the era of the Abbasid dynasty, not many Arabs, especially Muslims, knew the importance of language codification or the compilation of Arabic dictionaries. According to Dr. Imel Ya'qu>b, there are at least three factors that cause the Arabs to not or late in the preparation of dictionaries, namely:

\section{a. The majority of Arabs are still illiterate (ummy)}

Before the arrival of Islam in the Arabian Peninsula, the Arabs who could read and write could be said to be very minimal. This fact causes the Arab people to pay less attention to the problem of codifying their language. Moreover, to collect the meaning of vocabulary and write it in the form of a dictionary.

\section{b. The tradition of nomadism and war}

In the Arabian peninsula, the population never settled. The shift from farmland to grassland and from prairie to farmland continues to occur and characterizes every phase of the history of the peninsula. In addition to the tradition of nomadism, the inhabitants

${ }^{6}$ Taufiqurrochman, Leksikologi Bahasa Arab, (Yogyakarta: UIN-Malang Press, 2008), h. 189.

${ }^{7}$ Fitra Hayani, "Leksikografi Arab (Sebuah Kajian Linguistik Terapan)". Shaut Al-'Arabiyah, Vol. 7, No. 1 (2019): 2. 
of the Arabian peninsula often fought between tribes and groups. The struggle for fertile land, springs, agriculture, and group fanaticism often causes wars among the people of the peninsula. In addition, their harsh characteristics and the desert region which always offers freedom of action without permanent law also trigger the occurrence of war. These things are the main reason for the Arabs to pay less attention to the tradition of reading and writing among them.

\section{c. Happier with spoken language}

It is undeniable that the Arabs are very fanatical about spoken language. They glorify the tradition of muha $>$ das $\backslash a h$, khita $>$ bah and poetry. Perhaps, geographically the desert region is deserted and migration habits also played a role in creating a literary tradition among them. The Sahara desert is not just a vast dune, but also nature that provides freedom to contemplate, imagine, pronounce words carefully, and promises enjoyment with poetry and eloquence. For the Arabs, verses of poetry have become evidence and guidelines for their lives. To understand the meaning of a word, they often refer to a collection of poems or muha>das lah contexts commonly used by desert people. ${ }^{8}$

The three factors mentioned above have resulted in the Arabs being left behind with other nations in terms of language codification or the preparation of Arabic dictionaries. Even so, it does not mean that before the era of the Abbasid dynasty, the Arabs did not know a dictionary at all, because lexicology, in the sense of the science that seeks to reveal meaning, has become a conversation in the Arabian peninsula. The ideas of the lexicon are growing rapidly among Arabs, especially Muslims, along with their activities to understand and interpret the holy verses of the Qur'an. ${ }^{9}$

\section{Systematics of Compilation of Arabic Dictionary}

Broadly speaking, there are two systematic models for compiling Arabic dictionaries used by lexicologists, namely the meaning system (ma'ani dictionary) and the pronunciation system (alfaz dictionary). ${ }^{10} \mathrm{With}$ the following description:

\footnotetext{
8 إميل يعقوب، المعاجم اللغوية العربية بداءتها وتطورها، (بيروت: دار العلم للملايين)، ص. 24.

${ }^{9}$ Taufiqurrochman, Leksikologi Bahasa Arab, (Yogyakarta: UIN-Malang Press, 2008), h. 197. 10 سالم سليمان الخماس، المعجم وعلم الدلالة، (جدة: لسان العرب، 1428هـ)، ص. 197.
} 


\section{a. Meaning System (Ma'ani Dictionary)}

That is the model of compiling vocabulary (items) in the dictionary used by a lexicologist by arranging words/dictionary entries sequentially based on the meaning of groups of vocabularies whose meaning is in the same plane (thematic). In other words, the grouping of entries in ma'ani dictionaries puts forward the aspect of meaning related to the topic/theme set by the lexicologist. For example, the word curriculum, teaching materials, books, students, lecturers, all entries are included in the theme/topic of education (tarbiyah). Or the word computer, mouse, laptop, the keyboard is inserted into the computer theme (technology), and so on. With systematics like this, the Ma'ani dictionary is more accurately called a thematic dictionary.

The emergence of ma'a>ni dictionaries was motivated by the sima>'i method of searching for vocabulary meaning, in which lexicologists went directly to the field or into the interior of Bedouin Arabia to hear their dialogue and language. After that, they recorded whatever their findings were without knowing the systematics of organized bookkeeping. Lexicologists only classify vocabulary based on the theory of al-huq>ul aldala>liyah (semantic field). This field of meaning theory attempts to classify a collection of meanings or vocabulary that is still included in the field/theme based on its meaning. Several well-known Arabic thematic dictionaries (ma'ani) include the al-gari>b almus \}annaf dictionary by Abu Ubaid (d. $224 \mathrm{H}$ ), the al-munajjad dictionary compiled by Kurra' al-Naml, the maba> dictionary di' al-lugah by Al-Iskafi, and al-mukhas \}s \}as \} by Ibn Sydah (d. 458).

\section{b. Pronunciation System (Alphaz Dictionary)}

That is a dictionary in which the words (items) in it are arranged sequentially based on the order of pronunciation (index) of the collected vocabulary, not looking at the meaning of the word. Since the emergence of the first Arabic dictionary, mu'jam al-'ai>n which was introduced by Khali>l bin Ahmad Al-Fara>hi>di, the systematic compilation of alfaz\} dictionaries has continued to grow rapidly in line with the needs of dictionary users. Searching for the meaning of words by looking at the pronunciation has become a trademark of Arabic dictionaries. Thematic dictionaries are only seen as books that discuss the interpretation of meaning as books of interpretation of the Qur'an and no longer as a language dictionary. 
At least in the history of the development of the Arabic lexicon, there are five systematic models (niz $\} a>m$ tarti $>b$ ) that have been used by Arab lexicologists in compiling pronunciation dictionaries, namely niz $\} a \mathrm{a}$ al-s $\}$ auti (phonetic system ), niz $\} a>m$ alfaba'i al-kha>s\} (special alphabetic system), niz $\} a>m$ al-qa $>$ fiyah (rhyme system), niz $\} a>m$ alfaba'i al-'a> m (general alphabetical system), and niz $\} a>m$ al-nut \}qi (articulation system). ${ }^{11}$

\section{1) Nizham Al-Shauti (Phonetic System)}

The factors behind Khali>l bin Ahmad Al-Fara>hi> in compiling a dictionary with this phonetic system are: 1) avoiding repetition of words in the dictionary, 2) covering all material/words, 3) making it easier for readers to find the meaning of words, and 4 ) did not want to imitate the al-hijai (alphabetic) letter order system and his obsession gave birth to an Arabic dictionary that was different from other language dictionaries. The existence of a phonetic system used in the first period Arabic dictionaries born at the end of the 2nd century Hijri in the preparation of vocabulary is a plus for the great innovation inscribed by Khali>1 as the father of the Arabic lexicon. A phonetic dictionary is a dictionary that was born at the same time as the motivation of Muslims in codifying their language as a tool for interpreting the Qur'an, so it is not excessive if Khali $>1$ chose the rules of tajwid (makha>rijul huru>f) as the basis for alphabetical arrangement. Khali $>1$ style. Bearing in mind, the science of qira'at is the first methodological science that developed among Muslims before other sciences. Therefore, Khali>l's work was widely accepted among commentators. The al-'ai>n dictionary, which uses a phonetic system, turned out to be the basis for generations after Khali>1 in compiling Arabic dictionaries. The proof is that several dictionaries immediately appeared using phonetic systematics. The phonetic system was considered the standard system in the preparation of Arabic dictionaries in the early 2nd century Hijri. However, the phonetic dictionaries that emerged after the al-'ai>n dictionary have some differences and additional principles. But basically, the works of post al-'ai>n are still guided by the phonetic system introduced by Khali $>1 .{ }^{12}$ 


\section{2) Nizham Al-Alfaba'i Al-Kha>s\} (Custom Alphabetical System)}

Nizham Al-Alfaba'i Al-Kha>s\} is an alpha>z\} dictionary compilation system introduced by Abu Bakr bin Duraid through his dictionary entitled jamharah al-lugah or better known as the al-jamharah dictionary. That is the system of arranging the order of words in the dictionary based on the hijaiyah letter sequence that has been compiled by Nasr bin Ashim, namely the order of letters from alif, ba, ta, s|a, and so on until the letter yes as we know it today. There are two factors behind Ibn Duraid compiling a typical alfaba'i system, namely: 1) difficulty in finding the meaning of words in a dictionary that uses a phonetic system such as Khali>l's al-'ai>n dictionary and other dictionaries currently circulating. that. This difficulty is experienced by many people who do not know the order of letters based on makhraj, 2) the arrangement of hijaiyah letters (tarti>b al-hija'i) which was successfully compiled by Nasr bin As \} im, has been popular among the people. Moreover, the hijaiyah letter order is supported by the government and recognized by scholars and the public as a standard system in the preparation of Islamic books other than language dictionaries. With the existence of a dictionary that uses tarti>b al-hija'i, Ibn Duraid hopes that Arabic dictionaries can be more widely known. Remembering, the function of the dictionary is to make it easier for users to understand the meaning, not even to complicate the search for meaning which must require someone to know makha>rij al-huru>f. The birth of a dictionary with an alphabetical system that no longer uses the rules of makha>rij al-huru>f(rules of qiraat / tajwid), is considered a new chapter in the field of Arabic lexicology. The alphabetical system dictionary seems to be a pioneer in the birth of independent lexicology. With the alphabet, the style of lexicology can separate itself from the science of qiraat, recitation of recitation, and interpretation, so that it is again part of the field of linguistics studies (linguistics). ${ }^{13}$

\section{3) Nizham Al-Qafiyah (Poetry/Literary System)}

The emergence of Arabic dictionaries that use the al-qa>fiyah system (rhyme/literary) is a major change in terms of the system. It is called the al-qa>fiyah system, because the arrangement of the word order in the dictionary is based on the order of the last

${ }^{13}$ Taufiqurrochman, Leksikologi Bahasa Arab, (Yogyakarta: UIN-Malang Press, 2008), h. 236243. 
letters of a word in the dictionary, no longer based on the sequence of letters in makha>rij al-huru>f (phonetic system), or tarti>b hijaiyah ( special alphabetical system), but is based on the last letter. The first person to introduce the al-qa>fiyah system was Isma>i>1 bin Ahmad Al-Jawhari from Bas \}rah with his dictionary entitled al-s \}iha $>$ h fi al-lugah or known as the al-s \}iha dictionary. $>$ h. There are four factors behind the emergence of the al-qafiyah system of dictionaries, namely: 1) Al-Jawhari's obsession to create innovative dictionaries with a new system, considering that the existing dictionary compilation systems were inconsistent, 2) the needs of the literary community for dictionaries. which can collect a collection of words that have the same rhyme, 3) Arabic words cannot be separated from the derivation process (isytiqa $>\mathrm{q}$ ). Al-Jawhari noticed that the last letter in a word, especially the letter la $>\mathrm{m}$ in wazan fi'il, always does not change. Unlike the letters fa and 'ai>n in wazan fi'il, 4) the emergence of many literary works such as poetry, prose, qasidah, songs, proverbs, and so on that use poems or end in the same letter. This phenomenon encourages Al-Jawhari to use the al-qa>fiyah system which is indeed appropriate and easy for people to find the meaning of words. The added value of a qa>fiyah system of dictionaries, among others, facilitates the search for the meaning of words and helps writers in understanding literary works or who want to compose poetry, poetry, prose, and so on. Meanwhile, the weakness of the qa>fiyah-system dictionary is that the tajri>d technique is still used in finding the meaning of words. The tajri>d technique also requires a correct understanding of grammar, especially neuroscience (morphology). For ordinary people or non-Arabs, the difficulty of finding the meaning of words in the dictionary is due to a lack of knowledge about neuroscience which takes a long time to master the field of science. $^{14}$

\section{4) Nizham Al-Alfaba'i Al-'A>m (Common Alphabetical System)}

The general alphabetical system is the arrangement of words in the dictionary based on the hijaiyah letter sequence that we know today, from the letters alif to yes. However, the difference between the general alphabetical system and the specific alphabetical system lies in the aspect of the root word (us $\} \mathrm{u}>1$ al-kalimah). The added value of a

${ }^{14}$ Taufiqurrochman, Leksikologi Bahasa Arab, (Yogyakarta: UIN-Malang Press, 2008), h. 245- 
dictionary with a general alphabetical system is that it is relatively easier for dictionary users to find the meaning of a word when compared to dictionaries with a phonetic, special alphabet, or qa>fiyah system. The loss of principles such as tarti $>\mathrm{b}$ al-huru $>\mathrm{f}$, taqsi $>\mathrm{m}$ al-bina $>$, and taqli $>\mathrm{b}$ al-kalimah, is quite innovative. This general alphabetical system dictionary practically only leaves the tajri $>d$ and tardi $>d$ principles which function to find out the origin of words (roots) and this function has long been applied by grammarians in the preparation of Arabic dictionaries with any system. ${ }^{15}$

\section{5) Nizham Al-Nuthqi (Articulation System)}

Even though the emergence of general alphabetical system dictionaries is considered the easiest of the previous systems, but these dictionaries still require an understanding of the basics of Arabic grammar. For students at the beginner level or even for nonArabs, word search using tajri $>d$ and tardi $>d$ techniques to find the origin of words according to wazan in morphology is still considered difficult and requires a long process. This problem has become a consideration for Arabic language experts to make an easier dictionary, especially for non-Arabs. After referring to foreign dictionaries, such as French dictionaries, which do not need to look for root words first in the process of finding the meaning of words, Arabic lexicologists began compiling dictionaries using an articulation system. The articulation dictionary system (niz $\} a>m$ al-nut qi) is a search for the meaning of a word based on the first letter spoken and the word being searched for can be found directly in the dictionary material, without having to require someone to look for the root of the word. Thus, the advantages of articulation system dictionaries lie in the aspect of ease of finding the location of vocabulary so that ordinary users can quickly find the meaning of words in the dictionary even though they do not understand the rules of neuroscience. And for dictionary compilers, the articulation system is very helpful in the process of clarifying selected words into word groups quickly without having to look for word origins, word derivations, and types of word structures (bina). The articulation system is considered the right system in the preparation of translated dictionaries so that non-Arabic users are easier to find and understand the meaning. In addition, along with the development of software technology, the quantity of word materials in articulation dictionaries which are usually

15 Taufiqurrochman, Leksikologi Bahasa Arab, (Yogyakarta: UIN-Malang Press, 2008), h. 257- 
large in number, is no longer an obstacle for programmers or developers of digital dictionaries. Given, now software can accommodate millions of bytes. On the other hand, if the word material in the articulation dictionary is written manually into a book, it usually forms a thick dictionary and even volumes. And this is the weakness of the articulation system dictionary. Another drawback of articulation system dictionaries is the neglect of word origin search techniques. In the perspective of language education, this is seen as a degradation of the quality and skills of dictionary users, especially for Arabic language learners. The articulation dictionary system causes them to no longer pay attention to the rules of neuroscience and nahwu science because grammatical rules are not very useful in finding the meaning of words in the dictionary. ${ }^{16}$

\section{Arabic lexicologists}

Here is a brief biography of Arabic lexicologists, their thoughts and works, namely:

\section{a. Khalil bin Ahmad Al-Farahidi}

His full name is Abdurrahman Khali>l bin Ahmad bin 'Amr bin Tami >m AlFara>hi> in Al-Bas\}ri (100-170 H/718-786 AD). Khali>l is an Arab native, born in the village of Azad, Oman. However, he grew up and studied religious sciences in the city of Basra, Iraq. In some books, Khali $>1$ is better known as Al-Fara>hi>di. The title is attributed to the tribe of his ancestors, namely Farhud, one of the tribes in the village of Azad, Oman. Khali>1 is someone who is blessed with brain intelligence and high creativity by Allah SWT. He is a true lover of knowledge. He likes to travel from one village to another that is far apart just to take narrations from the villagers to understand the meaning of a word. Many of his theories are formed from the results of scientific research in the field. Khali>1 was willing to hang out with the Bedouin Arabs in the interior to understand the meaning of the language. His life was spent on the development of the Arabic language and literature. ${ }^{17}$

Khali>1 grew to become one of the greatest scholars in the field of Arabic linguistics. He is a scholar who mastered the science of nahwu (syntax), linguistics (linguistics), and Arabic literature. In addition, he is also qualified in the fields of mathematics, sharia (Islamic law), and the art of music. Through his work entitled mu'jam

16 Taufiqurrochman, Leksikologi Bahasa Arab, (Yogyakarta: UIN-Malang Press, 2008), h. 269-

17 Taufiqurrochman, Leksikologi Bahasa Arab, (Yogyakarta: UIN-Malang Press, 2008), h. 286.
} 
al-'ai $>n$, Khali $>1$ is known as the founder of the foundations of lexicology, so it is not an exaggeration to call Khali>1 the "father of Arab lexicologists". More than that, Khali>1 also deserves to be called the first person who succeeded in compiling the rules of 'aru $>d$ \} science, namely the science of studying poetry and verses. Through his work entitled Kitab al-'aru>d\}, Khali>1 composes the rhythm and wazan qafiyah for Arabic literary works. $^{18}$

Some of Khali>l's works that have been accessible up to now include: al-nut \}q wa al-syakl (dots and vowels), al-nig >am (a collection of songs), al-'aru>d\} (the science of poetry). , syawa $>$ hid (collection of poems), al-jama>l and al-'iqa>. ${ }^{19}$

\section{b. Abu 'Amr Al-Syaibani}

Abu 'Amr Ishaq bin Mura>r Al-Syaibani (110-206 H/728-821 AD) was born in the village of Ramada>t, close to the city of $\mathrm{Ku}>\mathrm{fah}$. His mother was from the Nabtiyah tribe and his lineage was continued to the Bani Syaiban. From $\mathrm{Ku}>$ fah, $\mathrm{Abu}$ 'Amr moved to the city of Baghdad and remained there until he died. Abu 'Amr is the scholar who best understands the dialect and language of the Arabs, even he is known as the scholar who understands the most about foreign sentences (gari>b nawadir). Since he was a teenager he liked to study Arabic with his friends in all corners of the city of Damascus. Abu 'Amr was willing to go to remote villages and mix with the Bedouin people in the interior to understand the dialect and Arabic language they spoke. Finally, he also wrote several books that contain collections ( $\mathrm{di}>$ wan) languages and dialects of the $\mathrm{Ku}>\mathrm{fa}$ and Baghdad people at once. His most famous teachers are Al-Mufad $\}$ d $\}$ al al-D \{abi and Al-Muhaddis $\backslash$ Rukn Al-Syami. While the students of Abu 'Amr, including: 'Amr (his son), Imam Ahmad bin Hambal, and Abu Ubaid Al-Qa>sim bin Sala>m. ${ }^{20}$

Abu 'Amr's life was spent searching for the history of ancient poems in remote villages and looking for linguistic data to support his research. Abu 'Amr managed to compile more than 80 books of di>wan (collections of poetry) from various tribes that he had approached. Almost every tribe has made di>wan which contains poems from the tribe. This achievement made Abu 'Amr known as a scientist and writer who cared about

18 خليل بن أحمد الفراهيدي، العين، ( CD Maktabah Al-Syamilah versi 2 bagian bithaqah,Global

(Arabic Encylopedia http://www.mawsoah.net

${ }^{19}$ Taufiqurrochman, Leksikologi Bahasa Arab, (Yogyakarta: UIN-Malang Press, 2008), h. 287.

${ }^{20}$ Taufiqurrochman, Leksikologi Bahasa Arab, (Yogyakarta: UIN-Malang Press, 2008), h. 287. 
the development and preservation of the Arabic language. He is also noted as the compiler of the first thematic dictionary in the history of Arabic lexicology. Some of his works, among others: dictionary al-ji $>\mathrm{m}$, al-khail, al-luga $>$ t, al-nawa $>$ dir al-kabi $>$, gari $>b$ alhadi>sl, al-nahlah, al- ibil, and khalq al-insa>n. Of the many titles of his books, the book huru>f fi al-lugah or known as the Kitab al-ji $>\mathrm{m}$ is a dictionary that has a major influence on the development of Arabic lexicology. Al-ji $>\mathrm{m}$ dictionary is a thematically arranged meaning dictionary. The choice of the letter $\mathrm{ji}>\mathrm{m}$ as the title of the dictionary has outwitted other scholars. They think that the order of letters arranged in the al-ji>m dictionary starts from the letter $\mathrm{ji}>\mathrm{m}$ like the al-'ai>n (Khali>l) dictionary which starts from the letter 'ai $>n$. The al-ji $>$ m dictionary starts from the letter alif to the letter yes according to the order of the hijaiyah letters. ${ }^{21}$

\section{c. Abu Mansyur Al-Azhari Al-Hawari}

His full name, Abu Mansyur Muhammad bin Ahmad Al-Azhari Al-Hawari (282$370 \mathrm{H} / 895-981$ AD). He was given the title Al-Hawari because he was born and died in the village of Hirah, Khurasan. While his popular name is Al-Azhari. This name is attributed to his grandfather named Al-Azhar, a prominent fiqh scholar in Khurasan. Abu Mansyur Al-Azhari grew up in the Qaramit $\}$ ah area, an area in Hawazin where the population always communicates with Arabic fus $\}$ hah. ${ }^{22}$

It seems that the social community around Abu Mansyur Al-Azhari who always upholds the Arabic language fus $\}$ hah and rejects the intervention of the Arabic language 'ammiyah (market) has influenced Al-Azhari's soul so that he can speak Arabic fluently and has a high fanaticism towards Arabic. fus \}hah. Therefore, he gave his dictionary the title tahzli>b al-lugah which means "an attempt to justify or restore the purity of the Arabic language". On the part of Muqaddimah he said, "I named my dictionary tahzli>b al-lugah, because I intend to collect the Arabic language that has been compiled before and delete all Arabic that has ever been intentionally included in Arabic. I will return Arabic to its original correct structure (fus $\}$ hah). Besides that, I also take care of this dictionary with all my might so that there are no typographical errors (tashif). I also don't want to prolong the discussion and reproduce unnecessary word material in a dictionary.

${ }^{21}$ Taufiqurrochman, Leksikologi Bahasa Arab, (Yogyakarta: UIN-Malang Press, 2008), h. 288. 22 أبو منشور الأزهاري، تهذيب اللغة ( CD Maktabah al-Syamilah versi 2, bagian bithaqah, Global 
Here, all garri $>\mathrm{b}$ (foreign) words/sentences narrated from narrators who are not istiqah (strong memorization), I will definitely throw them away". ${ }^{23}$

Al-Azhari Dictionary is a dictionary that uses phonetic systematics (niz $\} a>m$ als\}auti) like Khali $>$ l's al-'ai $>n$ dictionary. Although the tahzli $>b$ al-lugah dictionary is more original than Al-Azhari's work, it does not make a major contribution and influence on the development of lexicology. Given, the dictionary is considered to follow the phonetic systematics released by Khali>1. In addition, none of the scholars used the tahzli>b al-lugah dictionary as an object of study, except for Abdul Karim bin At \}oillah Al-Iskadari who compiled a summary of the tahzli $>b$ al-lugah dictionary with the title mukhras\}ar al - tahzli $>$ b. Nevertheless, the lexical meanings in the tahzli $>b$ al-lugah dictionary are still used as references by generations of scholars after Al-Azhari. For example, Al-S \}agani (1181-1252 AD) in his work Mukhta>r al-sahi>h, then Ibn Manz \}ur (1232-1311 AD) through his oral dictionary al-'arab, and several other scholars who claim to have made tahzli>b al-lugah dictionary as a reference in understanding lexical meaning. ${ }^{24}$

The original manuscripts of the tahzli $>b$ al-lugah dictionary are 18 manuscripts. The largest manuscript is in the 'A>rif library in the city of Medina which was written by a khatta>t $\}$ named Yaqut Al-Hamawi in $616 \mathrm{H}$. The tahzli $>$ b al-lugah dictionary was first printed in 1964 in Egypt after going through the process of editing done by language scholars. $^{25}$

\section{d. Ismail bin Qasim Al-Qali Al-Bagdadi}

Ismail bin Qasim bin Harun (901-967 AD) was born and grew up in Manazjarad, which is located in the East Furat area, near Bahirah, Baghdad. Al-Qa>li title behind his name, because he often associated with a tribe called Qa>li in Baghdad. While the nickname Al-Bagdadi was addressed by the Andalusian population to Ismail bin Qasim after he arrived and settled there. Ismail Al-Bagdadi's work is called the al-ba>ri' dictionary, the first dictionary to appear in the Andalusian region. In addition, he also wrote a book entitled al-nawa $>$ dir, and al-maqsu $>d$ wa al-mamdu $>d$ wa al-mahmu $>$ z, all

23 أبو منشور الأزهاري، تهذيب اللغة ( CD Maktabah al-Syamilah versi 2, bagian bithaqah, Global

(Arabic Encylopedia, http://www.alwaraq.net, http://www.mawsoah.net

${ }^{24}$ Taufiqurrochman, Leksikologi Bahasa Arab, (Yogyakarta: UIN-Malang Press, 2008), h. 290.

25 Taufiqurrochman, Leksikologi Bahasa Arab, (Yogyakarta: UIN-Malang Press, 2008), h. 291. 
about Arabic grammar. Ismail Al-Bagdadi was one of the students of Ibn Duraid, the author of the al-jamharah dictionary. At first, Ismail compiled an al-ba>ri 'dictionary using a special alphabetical systematic following the pattern of his teacher, Ibn Duraid. However, he felt that Khali>l's phonetic system was still needed in the preparation of Arabic dictionaries in the era of language codification. In addition, Ismail admits that his knowledge of Ibn Duraid's special alphabetic system is still minimal and Ibn Duraid's work has not been widely known and acknowledged by other linguists. For reasons of content, Ismail Al-Bagdadi insisted on returning to the phonetic system, even though the system was more difficult for dictionary users in Andalusia. Ismail Al-Bagdadi's choice of the phonetic system in his dictionary, al-ba>ri', is clearly less popular than his predecessor, al'ai $>\mathrm{n}$. This is what makes not many linguists seriously research the alba>ri' text, except for Ismail Al-Bagdadi's student, namely Abu Bakr Al-Zabaidi through his work al-mustadrak min al-ziya $>$ dah fi $>$ us $>$ b al-ba $>$ ri' ala us $>$ b al-'ai $>$ n (explanation of the addition of the al-ba>ri' dictionary to the al-'ai>n dictionary). ${ }^{26}$

\section{e. Ibnu Duraid}

His full name is Muhammad bin Al-Hasan bin Duraid Al-Azdi (321-233 H/838933 AD). Ibn Durai was born in Bas \}rah, then moved to Oman and lived there for 12 years, then he returned to Bas \}rah, Iraq. Ibn Duraid is known as an expert on language and literature. He likes to travel from place to place to study languages and strengthen his writings. He had traveled to the outskirts of Persia. His odyssey in Iraq is recorded in Alu Mikal's diwan faris. However, in the end, he preferred to return to Baghdad during the Abbasid dynasty led by Al-Muqtadir. Ibn Duraid is a scientist who is financed by the state. Every month he gets a salary of 50 dinars for his services in the field of linguistic knowledge. He used his entire life to produce scientific works that played a major role in the development of grammar which was growing rapidly in Basra, Iraq. Ibn Duraid died in Baghdad at the age of $95 .^{27}$

In addition to his dictionary, al-jamarah or jamarah al-lugah which consists of three volumes, Ibn Duraid's other works are al-isytiqa $>\mathrm{q}$ (the science of lineage), al-maqsu $>\mathrm{r}$ wa al-mamdu>d (the science of s $\}$ araf ), al-mujtaba, taqwi $>\mathrm{m}$ al-lisa $>\mathrm{n}$, dakhair al-

${ }^{26}$ Taufiqurrochman, Leksikologi Bahasa Arab, (Yogyakarta: UIN-Malang Press, 2008), h. 291292.

${ }^{27}$ Taufiqurrochman, Leksikologi Bahasa Arab, (Yogyakarta: UIN-Malang Press, 2008), h. 292293. 
hikmah, syifah al-sira>j wa al-lija >m, al-mala>hin, al-sahab wa al-gais|, adab al -ka>tib, al-amaly, al-wisyah, zuwar al-'arab, and al-luga>t. Ibn Duraid's Al-Jamarah Dictionary is the first dictionary to use a special alphabetical system. He dared to be different by putting aside the models of phonetic dictionaries which at that time were oriented to Khali>l's al'ai $>$ n dictionary. However, the word materials in Ibn Duraid's dictionary take a lot from the al-'ai>n dictionary. In fact, in terms of explanation of meaning (syarah), style of language (uslu>b), and argumentation (istisyha $>d$ ), the dictionaries of al-Jamarah and al'ai $>\mathrm{n}$ can be said to be almost the same. This then drew criticism from several parties who accused Ibn Duraid of not being a lexicologist, because he was considered to only be able to replace the al-'ai>n dictionary with a different (systematic) cover, while its content still boils down to the al-'ai>n dictionary. ${ }^{28}$

Al-Jamarah dictionary can be said to have a less significant influence on the development of Arabic lexicology. This is understandable because Ibn Duraid is still under the shadow of Khali>l in terms of compiling a dictionary. Moreover, the systematic hijaiyah alphabetical order carried by Ibn Duraid only followed the creations of Nas \}r bin As $\} \mathrm{i}>\mathrm{m}$ who had previously arranged hijaiyah letters sequentially from the letters alif to $\mathrm{ya}^{\prime}{ }^{29}$

\section{f. Ibnu Faris Al-Razi}

Abul Husain Ahmad bin Faris bin Zakaria bin Hubaib Al-Qazwini Al-Razi (329395 H/941-1004 AD), that's the full name of Ibn Faris. There is another opinion that says that his real name is Ahmad bin Zakaria bin Farris. Like other scientists, Ibn Farris also likes to travel in search of knowledge. He had studied hadith| at the majlis of hadith science $\}$ in the city of Baghdad. However, the longest place inhabited by Ibn Faris was the city of Hamzan before he finally moved to the city of Rai and died there. ${ }^{30}$

The most influential teacher in shaping the personality of Ibn Faris was his father, Faris bin Zakaria. Atah he is a fa>qih, linguist and also a writer. Ibn Fa>ris learned a lot about the Shafi'i school of jurisprudence from his father and he became a follower of the Shafi'iyah school, although, in the end, he moved to the Malikiyah school when he lived 294.

${ }^{28}$ Taufiqurrochman, Leksikologi Bahasa Arab, (Yogyakarta: UIN-Malang Press, 2008), h. 2913-

${ }^{29}$ Taufiqurrochman, Leksikologi Bahasa Arab, (Yogyakarta: UIN-Malang Press, 2008), h. 295. 297.

${ }^{30}$ Taufiqurrochman, Leksikologi Bahasa Arab, (Yogyakarta: UIN-Malang Press, 2008), h. 296- 
in the city of Rai. When he was asked about his move to the Maliki school, Ibn Faris replied, "I just want to preserve the great name and glory of Imam Maliki in Rai, a place that has been Maliki school since the beginning". ${ }^{31}$

Ibnu Faris is not only qualified in the fields of lexicology and linguistics, but he is also a scholar who has complete abilities in various fields. This can be seen in his writings covering various fields of science. At least, there are 45 books written by Ibn Faris, including: al-ittiba' wa muza>wijah, ikhtila>f nahwiyyi>n, akhla>qun Nabi, us $\}$ u $>$ lul fiqh, al-ifra $>$ d , al-amaly, ams|ilatu asja', al-ta>j, al-intis $\}$ ar li $>$ s $\mid a ' l a b$, tama $>m$ fas $\}$ i $>h$ al-kala $>$ m, ja $>$ mi' al- ta'wi $>1$, hilyatul fuqaha $>$ ', khalqul insa $>n$, muqaddimah al fara $>i d\}$, and others. ${ }^{32}$

The greatest work of Ibn Faris is the maqa>yis al-lugah dictionary and the almujmal dictionary. These two books contributed greatly to the development of Arabic lexicology. Through his work, Ibn Faris tried to deny the principle of taqlibul kalimah ala Khali $>1$ and replaced it with the theory of al-us $\} \mathrm{u}>1$ wa al-maqa>yis which was later known by Arabic linguists as al-isytiqa $>\mathrm{q}$ al- akbar (high derivation). A theory that serves to reveal the veil of original meaning through words that have the same meaning and that can be known from the derivation of the root words. In other words, a collection of words that come from the same us $\} \mathrm{u}>1$ (root) often have almost the same miqya $>$ s (size) meaning. ${ }^{33}$

The new findings put forward by Ibn Faris made linguists recognize the credibility and thoroughness of Ibn Faris in understanding Arabic. With the emergence of the theory of al-us $\} \mathrm{u}>1$ wa al-maqa>yis, the technique of finding the meaning of words with the taqlibul kalimah principle which is commonly used in phonetic dictionaries, began to be abandoned, so that the emergence of this dictionary by Ibn Faris was able to emphasize the existence of a special alphabetic system that had previously been introduced by Ibn

\footnotetext{
31 أحمد بن فارس، مقايس اللغة (CD Maktabah Syamilah versi 2, http://www.awu-dam.org)، جزء

${ }^{33}$ Taufiqurrochman, Leksikologi Bahasa Arab, (Yogyakarta: UIN-Malang Press, 2008), h. 298.
} 
Duraid, but did not succeed in boosting the popularity of the alphabetical system to rival the phonetic system. ${ }^{34}$

\section{g. Ibnu Jinni}

Ibn Jinni's full name was Abul Fath Us|man bin Jinni Al-Mus \}ily (320-390 H/932$1001 \mathrm{AD})$. He is a well-known scholar in the fields of nahwu and literature. His childhood was spent in the city of Mosul, Iraq. It is said that his father worked as a loyal assistant to a judge in Mosul named Sulaiman bin Fahd Al-Azdi. Even so, this social status did not dampen Ibn Jinni to study and obtain education like other children. Since childhood, he has been gifted with a scientific zeal or a strong zeal to learn from the sheikhs in the area of his birth. Almost all halaqah (taklim assemblies) have been attended by Ibn Jinni to seek knowledge from caregivers and sheikhs who are experts in their respective fields. At a young age, 17 years old, he has mastered neuroscience. Until Ibn Jinni became acquainted with a sheikh named Abu Ali Al-Farisi who was known as an expert in linguistics and nahwu in his day. Since then, Ibn Jinni made his choice to only study from Abu Ali Al-Farisi and leave another halaqah. For 40 years, Ibn Jinni became a loyal student of Abu Ali Al-Farisi until he inherited all knowledge from his teacher. ${ }^{35}$

Scientific works written by Ibn Jinni reached 67 books. However, his most popular book to date is al-khas \}ais \}, a book whose comprehensive content includes the basics of nahwu, the rules of fiqh and nahwu, and a lexicological analysis of the meanings of Arabic vocabulary. This book, which consists of 162 chapters, was once presented to Sultan Baha'uddin Al-Buwaihi, precisely after Ibn Jinni's teacher died. In the field of fiqh, Ibn Jinni followed the Imam Hanafi madhhab, in the field of aqidah, he preferred to be a follower of the mu'tazilah and in the field of nahwu he leaned towards the Bas \}rah scholarly school. Some of Ibn Jinni's opinions that sparked controversy in the book Khas \}ais \}, among others: his criticism of the shortcomings of Sibawaih's A-Kita>b and his opinion which stated that Arabic language knowledge is an Islamic faith. ${ }^{36}$

\footnotetext{
34 Taufiqurrochman, Leksikologi Bahasa Arab, (Yogyakarta: UIN-Malang Press, 2008), h. 299.

35 Taufiqurrochman, Leksikologi Bahasa Arab, (Yogyakarta: UIN-Malang Press, 2008), h. 300.

CD Maktabah Syamilah versi 2, bagian bithaqah dan An al-kitab, (بن جني، الخصائص 


\section{h. Ismail bin Hammad Al-Jawhari}

Ismail bin Hammad Al-Jawhari (d.393 H/1003 AD) came from the village of Farab. Since childhood, he has entered Iraq, then he traveled to the Hijaz to the interior of the Bedouin villages to learn the dialect of the Arabs and the native poems of the villagers (Bedouin) who still have a fluent level of language and are not contaminated with dialectal influences from the West. immigrants. After long wandering, he returned to Khurasan and settled in Naysabur. Besides being known as a creative Arabic expert and lexicologist because of his work, the two-volume al-s $\}$ iha $>\mathrm{h}$ fi $>$ al-lugah dictionary, he is also known as a person who died because of his creativity. It is said that Al-Jawhari called the residents of Naysabur to introduce one of his works in the form of a tool for flying. At that time, he tied his hands with wide wood like the wings of a bird, then he immediately flapped his hands like a bird about to fly. Not long after, he managed to fly into the sky, but finally, he fell because he was exhausted, then he breathed his last. ${ }^{37}$

The al-s $\}$ iha $>$ h dictionary as the first dictionary to introduce the al-qa $>$ fiyah system, clearly received great attention among scholars. The contribution of this system is considered very helpful for writers in compiling and understanding poetry in Arabic poetry and prose. The response of the scholars is evidenced by the emergence of other books that try to examine the al-S \}iha>h dictionary. Some scholars try to make a summary (ikhtis $\}$ a $>$ ) from the al-s $\}$ iha $>$ h dictionary as a form of acknowledgment and appreciation of the dictionary. ${ }^{38}$

\section{i. Ibnu Manzhur Al-Afriqi}

His full name is Muhammad bin Mukarram bin Ahmad bin Habqah Al-Ansari AlIfriqy (630-711 H/1232-1311 AD). His lineage was continued to Rumaifi 'bin S|abit AlAns $\}$ ari, one of the companions of Rasu>lulla>h SAW. Ibn Manz $\} \mathrm{u}>\mathrm{r}$ was born in the city of Cairo. Another opinion states that he was born in Tharablis. Ibn Manz $\} \mathrm{u}>\mathrm{r}$ is an expert in the fields of Arabic, history, and fiqh. Ibn Manz \}u>r's greatness can be seen in his writings called the lisa $>\mathrm{n}$ al-'arab dictionary, the largest and most complete dictionary of his time which was able to accommodate all the content of previous dictionaries, such

\footnotetext{
37 إسماعيل بن حماد الجوهري، الصحاح في اللغة (, Maktabah Syamilah versi 2,

h. Pendahuluan (bithaqah An Al-Muaalif) (http://alwaraq.net 304.

38 Taufiqurrochman, Leksikologi Bahasa Arab, (Yogyakarta: UIN-Malang Press, 2008), h. 301-
} 
as the al-muhka $>\mathrm{m}$ dictionary, al- $\mathrm{s}$ \}iha $>\mathrm{h}$, tahzli $>\mathrm{b}$ al-lugah, al-jamharah, al-niha $>\mathrm{yah}$, and hasyiyah al-s $\}$ iha $>h$. Scholars admit that reading this dictionary by Ibn Manz $\} \mathrm{u}>\mathrm{r}$ is like reading all the dictionaries of his predecessors. It is no exaggeration, if the lisa $>\mathrm{n}$ al'arab dictionary is classified as the most complete dictionary because it contains more than 80,000 words. The lisa>n al-'arab dictionary is also often used as an object of research by language scholars. Ibn Manz\}u $>$ r's other works, the majority of which are summary books (mukhtas $\} a>r$ ) of previous popular books so that he is known as a writer who is able to summarize the contents of large books and present them in a language that is clear. concise so that it is easily understood by the next generation. ${ }^{39}$

Among the writings of Ibn Manz \}u >r, namely: mukhtas \}ar al-aga>ni, mukhtas\}ar ta>ri>kh Baghdad (al-kha>tib al-bagdadi), mukhtas\}ar ta>ri>kh dimasyqa (Ibn Asa $>$ kir), mukhtas\}ar mufrada $>t$ Ibn bayt\}a $>r$, mukhtas\}ar al-aqd al-fari $>d$ (Ibn Abdu Rabbih), mukhtas\}ar al-hayawan (Al-Jahiz\}) , mukhtas\}ar yati>mah al-dahr (als|a'laby), mukhtas\}ar nisywan al-muha>d\}arah (Al-Tanawwukhi) and mukhtas\}ar aldakhi $>$ rah. $^{40}$

\section{j. Muhammad bin Ya'qub Al-Fairuzabadi}

The full name of the composer of al-qa>mu>s al-muhi>t\} is Abu T\}a hir Majduddi>n Muhammad bin Ya'qub bin Muhammad bin Ibra>hi>m bin Umar AlSyairazi Al-Fairuzabadi (729 -817 H/1319-1415 AD). He is popularly known as AlFairuzabadi. This linguist was born in the city of Karzen, Syairaz, a region in Persia in $729 \mathrm{H}$, precisely during the reign of the Mongols who had conquered Baghdad since 656 $\mathrm{H}$ until the Ottoman dynasty was able to control Egypt in $923 \mathrm{H}$. Al-Fairuzabadi was born 18 years since the death of Ibn Manz $\} \mathrm{u}>\mathrm{r}$, the compiler of the lisa $>n$ al-'arab dictionary. Since childhood, there have been visible signs of Al-Fairuzabadi as a candidate for great scholars. At the age of 7 years, he has been able to memorize the Qur'an and can write Arabic script with good khat. This natural talent prompted his father, Sheikh Sira>juddi>n Ya'qub to pay more attention to his son. Therefore, his father immediately taught him the Arabic language and literature, which at that time was booming in Syairaz. In addition, he was accompanied by his father to study with great scholars. Al-Fairuzabadi had studied

306.

39 Taufiqurrochman, Leksikologi Bahasa Arab, (Yogyakarta: UIN-Malang Press, 2008), h. 304-

${ }^{40}$ Taufiqurrochman, Leksikologi Bahasa Arab, (Yogyakarta: UIN-Malang Press, 2008), h. 307. 
S \}ahi >h Bukhari and Jami' Turmuz|i from Abu Abdilla>h Muhammad bin Yu>suf AlAns \}a>ri Al-Zarandi from Medina. Al-Fairuzabadi's work al-qa>mu>s al-muhi>t\} is included in a large Arabic dictionary which received an extraordinary response from scholars. Some give an explanation (syarah), criticism (naqd), defense (difa>'), and also a summary (ikhtis $\} a>r$ ). The use of the term al-qa $>m u>s$ which was popularized by AlFairuzabadi as the title of his work, was able to replace the term mu'jam which had long been introduced by Khali $>1 .{ }^{41}$

\section{k. Buthrus Al-Bustani}

But\}rus Al-Busta>ni was born in 1819 in a village called Dibyah, part of Shuf, Lebanon. Since childhood, he was fond of studying religious sciences, especially linguistics. His study period began at a madrasa named 'Ain Waraq, the largest madrasa in the Shuf area. There, he studied Arabic, Syriac, Latin, Italian, philosophy, theology, and Christianity. As for English, he is self-taught. But\}rus Al-Busta>ni is a prolific scholar. He can write various scientific works that can provide scientific contributions to the next generation. He even translated the Torah. His works cover various fields of science, such as morphology, syntax, linguistics, literature, and so on, including papers, lectures, and sermon material which are usually published in various magazines and newspapers. However, his most famous books are the encyclopedia dairatul ma'a>rif and the large muhi $>$ t \} al-muhi $>$ t \} dictionary.>

The muhi>t \} al-muhi>t \} dictionary had a big influence on the development of Arabic dictionaries that were published afterward, both in terms of material, meaning, and systematic preparation of data entry. In 1883, But \}rus Al-Busta>ni died. His name is recorded in gold ink as the first person who succeeded in establishing a national madrasa, the first person who succeeded in compiling the most comprehensive Arabic dictionary in Egypt, the first person who was instrumental in reviving the world of journalism in Egypt. $^{42}$

\section{Lewis bin Nuqala}

Lewis bin Nuqala D \}a>hir Al-Ma'lu>f (1867-1946) was born in the city of Zahlah, Lebanon. He is a pastor and follower of Christ. He began his further studies studying at 309.

${ }^{41}$ Taufiqurrochman, Leksikologi Bahasa Arab, (Yogyakarta: UIN-Malang Press, 2008), h. 307-

${ }^{42}$ Taufiqurrochman, Leksikologi Bahasa Arab, (Yogyakarta: UIN-Malang Press, 2008), h. 312. 
the Christian faculty school in Bairut. Then, he studied philosophy in England and went on to France to study theology. Lewis is able to communicate in several foreign languages. Lewis's work, which is still popular and has been reprinted many times, is almunji $>d$ 's dictionary. But actually, the material in the al-munji $>d$ dictionary takes a lot from the muhi>t \} al-muhi $>$ t (But \}rus) dictionary until the al-munji $>\mathrm{d}$ dictionary is better known as a summary of muhi $>$ t $\}$ al- muhi $>t$ t . A lexicologist, Fuad Afram Al-Busta>ni succeeded in compiling a summary of the al-munji>d dictionary, namely al-munji $>d$ alabjadi which was specifically compiled for students and users of the articulation system (niz $\} a>$ m nut $\}$ qi) ${ }^{43}$

\section{m. Abdullah Al-'Ulayali}

Sheikh Abdullsh Al-'Ula>yali is one of the great teachers in the field of language and fiqh. He was born in the city of Beirut, Lebanon in 1914. He studied at Al-Azhar University in Cairo, Egypt. His creative thoughts and ideas in terms of lexicology are outlined in his work entitled muqaddimah li dars al-'Arabic wa kaifa nad \}a'u al-mu'jam al-jadi>d (Introduction to Arabic Studies and Procedures for Compiling a New Dictionary), has been recognized by scholars of the language. In fact, this book is an encyclopedia of language, science, and art. However, the vocabulary material in this book stops at the letter alif, the word (ألس). Another work of Al-'Ula>yali is the dictionary almu'jam, a medium-sized dictionary that contains material about language and art. The almu'jam dictionary is structured with articulation systematics in which all vocabularies are sequenced and start from the word mufrad. Al-'Ula>yali also compiled another dictionary entitled al-marja' with the same systematic. However, like the previous work, both almu'jam and al-marja', have not been completed and only stop at the first volume. Even so, the use of a new systematic called niz $\} a>m$ al-nut $\} q$ (articulation system), remains an added value than Al-'Ula>yali's dictionary. ${ }^{44}$

\section{n. Ali bin Muhammad Al-Jurjani}

Ali bin Muhammad Al-Jurja>ni was born in 740H/1339 AD in the village of Taju, near Istira>baz|. Since he was a child, Ali Al-Jurja>ni was sent by his parents to the city of Hirah to study with Sheikh Qutbuddi>n Muhammad Al-Ra>zi Al-Tuhtani. After

\section{3.}

${ }^{43}$ Taufiqurrochman, Leksikologi Bahasa Arab, (Yogyakarta: UIN-Malang Press, 2008), h. 312-

${ }^{44}$ Taufiqurrochman, Leksikologi Bahasa Arab, (Yogyakarta: UIN-Malang Press, 2008), h. 314. 
studying at Hirah for a long time, then the teacher sent Ali Al-Jurjani to Sheikh Mubarak Shah, one of the great teachers of Jami' Al-Azhar Cairo, Egypt. Ali's intelligence amazed his teacher. Therefore, Sheikh Mubarak urged Ali to study with other teachers, one of whom was Sheikh Ali bin Muhammad Al-Fanari. ${ }^{45}$

The work of Ali Al-Jurja>ni which is still used as a reference in understanding the definition of a word or sentence is al-ta'ri>fa>t. A dictionary that uses an articulation system, so is considered easier to use in searching for vocabulary entries. Dictionary alta'ri>fa>t, first published in 1897 in Cairo. In addition, other works of Ali Al-Jurja>ni are syuru>h 'ala al-kasysyaf (Zamakhari), syarah al-tafta>za>ni (Al-Qazwini), syarah alfara $>$ id al-syira $>$ jiyah $\left(\right.$ Al-Sika $>$ liki). ${ }^{46}$

\section{o. Ibnu Sidah}

His full name is Abul Hasan Ali bin Isma>il (398-458 H/1007-1066 AD) but he is more popular with the name Ibn Sidah. He is one of the experts in the field of language and literature. Born in Mursiyah, east of Andalus, then he moved to Daniyah until he died there. It is said that he was known to be blind like his father, but his physical shortcomings did not reduce his enthusiasm for learning languages. Since he was young, he has often composed poetry and studied vocabulary. His most famous written work is almukhas $\} \mathrm{s}\} \mathrm{a}>\mathrm{s}\}$ as many as 17 volumes, a reference book in learning Arabic. In addition to language books, al-mukhas $\} \mathrm{s}\} \mathrm{a}>\mathrm{s}\}$ is a thematic dictionary that contains the meaning of Arabic vocabulary that was popular at that time. However, his famous and most complete dictionary work is al-muhkam wa al-muhi>t $\}$ al-a'z $3 a>m$ in 4 volumes, which was the most popular Arabic dictionary in his time until the era of Ibn Manz\}u $>r$, the oral compiler of al-'arab. Initially, in the project of compiling this large dictionary, he was supported by the Governor of Daniyah, Mujahid Al-Amiri. However, due to preoccupation with conquest (futuha>t), the project was discontinued and he was prohibited from compiling a dictionary. This obstacle did not dampen Ibn Sidah's heart to continue to complete the compilation of the dictionary which he had written long before there was support from the Governor of Sidah. According to Ibn Manz $\} \mathrm{u}>\mathrm{r}^{\prime}$ s confession,

45 علي بن محمد الجرجاني، التعريفات، (بيروت: علم الكتب، 1987)، ص. 14.

46 Taufiqurrochman, Leksikologi Bahasa Arab, (Yogyakarta: UIN-Malang Press, 2008), h. 315. 
"I have not seen a better Arabic book/dictionary than Al-Azhari's tahz \}i>b al-lugah dictionary and nothing more complete than Ibn Sidah's al-muhkam dictionary". ${ }^{47}$

\section{p. Ibnu Al-Sikkit}

Ibn Al-Sikki>t (186-244 H/802-858 AD), his real name was Abu Yusuf Ya'qub bin Ishaq. Actually, Al-Sikki>t is his father's title. This title was pinned on his father because he was known to be quiet. His father was a pious man and knowledgeable in the field of language and poetry. The father is also known to be happy and likes to teach small children in his village, Dauraq. His patience in teaching young children has succeeded in producing educated and dignified future generations, including his son. Later, he and his family moved to the Darbul Qant $\}$ arah area in the city of Salam. In his new place, he returned to teaching religious sciences and languages to small children. But this time, he was helped by his son, Ya'qub. Since childhood, Ya'qub had only studied under the guidance of his father. According to Al-Hamawi, when Ibn Sikki>t began to grow up, he could not contain his obsession to migrate to Bas \}rah and Kufa to study nahwu. Ibn Sikki $>t$ wrote a lot of ma'ani (thematic) dictionaries, including: al-d $\} a>d\}$ (antonyms), al-hasyara $>t$ (insects), al-naba>t (plants), al -wahsy (wild animal), al-ibil (camel), alisytiqa $>\mathrm{q}$ (derivative), al-as $\}$ wa $<\mathrm{t}$ wa al-alfa $>\mathrm{z}$ \} (voice and pronunciation) and several other works. All of his writings amounted to almost 40 titles. His greatest work, entitled is \}la $>\mathrm{h}$ al-mant iq, a book containing linguistics and logic which was best known in Baghdad in the era of Ibn Sikki>t. ${ }^{48}$

\section{CONCLUSION}

From the description that has been delivered in the end, several things that can be concluded are:

1. A dictionary as a reference book in finding the meaning of words is certainly very helpful in recognizing the meaning of new words. Lexicology which is a branch of linguistics that discusses lexical meanings, their development, and changes in meaning, from time to time continues to develop as part of linguistics and literature.

317.

${ }^{47}$ Taufiqurrochman, Leksikologi Bahasa Arab, (Yogyakarta: UIN-Malang Press, 2008), h. 316-

${ }^{48}$ Taufiqurrochman, Leksikologi Bahasa Arab, (Yogyakarta: UIN-Malang Press, 2008), h. 318. 
2. Language scientists in producing a scientific work, especially in the field of Arabic lexicon, have struggled so hard, tirelessly, traveling from one corner of the village to another to get and understand the meaning of a word. They spent their lifetime developing the scientific treasures of the Arabic language and literature to be passed on to generations of language and literary activists in the future. The majority of the scholars at that time were multitalented, not only qualified in one particular field of science, but also in several fields of knowledge at the same time which became their expertise..

3. The works of lexicologists in the form of dictionaries with various arrangement systematics in each era have characteristics that are adapted to the needs of dictionary users at that time. Every dictionary that is born has its own advantages and disadvantages. However, the contribution of lexicologists from the time of Khali>1 until now certainly plays a major role in the development of lexicology as part of linguistics, especially Arabic linguistics, and literature.

\section{REFERENCES}

Al Azhari, Abu Mansur. CD Maktabah al-Syamilah versi 2, bagian bithaqah, Global Arabic Encylopedia, http://www.alwaraq.net, http://www.mawsoah.net

Al Farahidiy, Khalil bin Ahmad. Maktabah Symailah.

Al-Jabiri, M. A. Formasi Nalar Arab, terj. Imam Khoiri, (yogyakarta: IRCiSoD).

Al Jauhariy, Ismail bin Humad. Ash Shihah fi al Lughah. (CD Maktabah Syamilah versi 2, http://alwaraq.net) h. Pendahuluan (bithaqah An Al-Muaalif)

Al Jurjani, 'Ali bin Muhammad. At Ta'rifat. Beirut: Ilmu al Kutub, 1987.

Al Khumas, Salim Sulaiman. Al Mu'jam wa 'Ilmu ad Dilaalah. Jedah: Lisan al 'Arab. 1428 .

Faris, Ahmad bin. CD Maktabah Syamilah versi 2, http://www.awu-dam.org

bin Muhammad, A., "Beberapa Aspek Keunikan dan Keistimewaan Bahasa Arab sebagai Bahasa Al-Qur'an”. Jurnal Teknologi, 42(E), (Juni 2005)

Hayani, F., "Leksikografi Arab (Sebuah Kajian Linguistik Terapan)". Shaut Al-'Arabiyah, Vol. 7, No. 1 (2019).

Jinni, Ibnu. Al Khashaish. CD Maktabah Syamilah versi 2, bagian bithaqah dan An alkitab, http://www.alwaraq.net, (http://www.mawsoah.net)

Taufiqurrochman. Leksikologi Bahasa Arab. Yogyakarta: UIN-Malang Press, 2008. 
HuRuf Journal : International Journal of Arabic Applied Linguistic http://dx.doi.org/10.30983/huruf.vlil.4714 क6

Creative Commons Attribution-ShareAlike 4.0 International License. Some rights reserved.

Ya'kub, Emil. Al Muajim al Lughawiyyah al 'Arabiyyah Badaatuha wa Tathawwuruha, Beirut: Dar al Ilm lil Malayin. 